
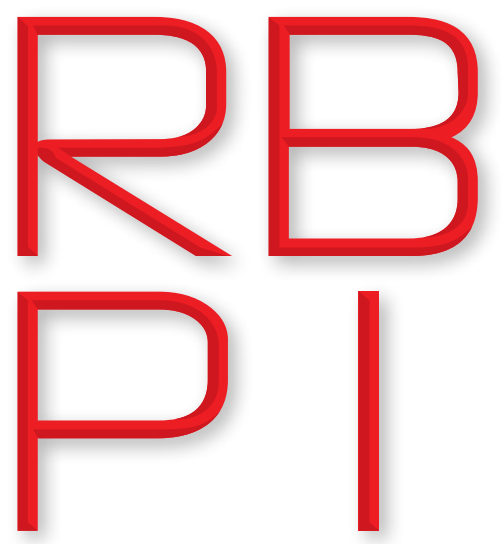

Revista Brasileira de Política Internacional ISSN 1983-3121

http://www.scielo.br/rbpi

\section{Anna Kotyashko}

Universidade de Minho, Escola de Economia e Gestão, Braga, Portugal (pg26713@alunos.uminho.pt).

iD ORCID ID

orcid.org/0000-0003-2288-9894

\section{Laura Cristina Ferreira-Pereira}

Universidade de Minho, Escola de Economia e Gestão, Braga, Portugal (Ipereira@eeg.uminho.pt).

iD ORCID ID:

orcid.org/0000-0003-4701-1113

\section{Alena Vysotskaya Guedes}

\section{Vieira}

Universidade de Minho, Escola de Economia e Gestão, Braga, Portugal (d4215@eeg.uminho.pt).

\section{Copyright:}

- This is an open-access article distributed under the terms of a Creative Commons Attribution License, which permits unrestricted use, distribution, and reproduction in any medium, provided that the original author and source are credited.

- Este é um artigo publicado em acesso aberto e distribuído sob os termos da Licença de Atribuição Creative Commons, que permite uso irrestrito, distribuição e reprodução em qualquer meio, desde que o autor e a fonte originais sejam creditados.

\section{Normative resistance to responsibility to protect in times of emerging multipolarity: the cases of Brazil and Russia}

DOI: http://dx.doi.org/10.1590/0034-7329201800101

\section{Abstract}

This article assesses the normative resistance to Responsibility to Protect adopted by Brazil and Russia against the backdrop of their international identities and self-assigned roles in a changing global order. Drawing upon the framework of Bloomsfield's norm dynamics role spectrum, it argues that while the ambiguous Russian role regarding this principle represents an example of 'norm antipreneurship', particularities of Brazil's resistance are better grasped by a new category left unaccounted for by this model, which this study portrays as 'contesting entrepreneur'.

Keywords: Normative resistance; Responsibility to protect; Responsibility while protecting; Brazilian foreign policy; Russian foreign policy; UN Security Council.

Received: June 19, 2017

Accepted: June 23, 2017

\title{
Introduction
}

$\mathrm{T}$ he underlying objective of the present article consists in assessing the normative tensions in effect within the international system as epitomised in the contested views of the principle of Responsibility to Protect (RtoP). This principle advocates international remedial responsibility to act when a state, either due to the lack of ability or willingness, fails to protect its population from the crimes of genocide, war crimes, ethnic cleansing, and crimes against humanity. After its endorsement in the 2005 World Summit Outcome Document (United Nations General Assembly 2005, \$138-139), one would expect a linear progression of RtoP towards its internalization by the states which have subscribed to it. However, the principle remains widely contested, particularly after the NATO-led intervention in Libya in March 2011, something which has jeopardised the legitimacy 
of RtoP, and hindered its consensual endorsement. Due to such intriguing normative dynamic, the investigation on this matter calls for further academic attention.

Among the most vocal critics of RtoP feature the countries belonging to the BRICS group, notably, Brazil, Russia, India, China, and South Africa. Given their criticism of the Libyan-style interventions, which imply regime change and are perceived as 'smokescreens' concealing other strategic objectives, the (re)emerging powers ${ }^{1}$ have often been described as "irresponsible" (Patrick 2010) and "spoilers" (Schweller 2011). As such, much of the literature characterises these countries' contesting behaviour as a part of the broader challenge to the liberal order while suggesting a degree of policy convergence on matters of global security (Vaz 2016, 23). However, the diverging stances adopted by the BRICS on the Syrian crisis demonstrate that their views of RtoP are more nuanced (Garwood-Gowers 2013). In this sense, there is more to the normative resistance of (re) emerging powers than is normally acknowledged.

The present work seeks to illuminate this subject matter against the backdrop of the norm diffusion dynamics in times of emerging multipolarity. Traditionally, norm evolution has been understood through the patterned model of norm life cycle, characterised by a three-stage process of norm emergence, followed by norm cascade, and norm internalization (Finnemore and Sikkink 1998, 895). According to this argument, the main advocacy mechanism relates to persuasion and normative entrepreneurship, and is generally adjudicated to powerful actors capable of socialising others into compliance (Bloomfield 2016, 313). Recent contributions have criticised this perspective for being too linear, whilst downplaying the agency of local actors, who are treated as passive norm followers (Acharya 2015; Wiener 2014). Conversely, the second wave of norm diffusion studies has devoted increased attention to the processes of resistance informed by local values. According to Wiener (2014), norms are carriers of a certain meaning-in-use and, therefore, may acquire a completely different meaning when combined with local cognitive priors. Moreover, contestation aimed at enhancing local agency can acquire different forms. As such, "localization" is meant to make an outside norm more congruent with a pre-existing normative order (Acharya 2015, 73). Local actors may also resort to "norm subsidiarity" to reaffirm global rules in the regional context or show resistance by offering alternative understandings (Acharya 2015). In this sense, norm development is perceived as a "multiple-agency, two-way, multi-step process" (Acharya 2015, 76).

Paying attention to the matter of normative resistance is also deemed important in the context of the nascent agency of other international actors beyond the West, which has been amplified by the current world (dis)order, characterized by the gradual transition of the international system towards multipolarity. Against the backdrop of power diffusion and decentralization, (re)emerging powers have been driven to contest the existing normative frameworks. Considering that RtoP encapsulates a complex conjunction of sovereignty and human rights, the implementation of this norm has been subject to challenge and reinterpretation by (re)emerging powers in an attempt

1 We chose to describe BRICS as '(re)emerging' powers because some of these states, namely Russia, China and India, have previously risen, fallen and are currently re-emerging as major players in the global governance. 
to increase their global actorness. As a result, RtoP has become "a new behavioural pattern in the making" (Baranovsky and Mateiko 2016, 67), for it represents a "key rallying point in the ideational skirmishes resulting from a changing global distribution of power" (Kenkel and Martins 2016, 22-23). Notwithstanding the recent surge in literature on norm resistance, few studies have systematically explored what accounts for the variation in (re)emerging powers' normative behaviour. Although there is some literature on individual perspectives of BRICS members on RtoP (Baranovskiy and Mateiko 2016; Job and Shesterinina 2014; Smith 2016), it remains rather limited concerning the explanation of differences in individual/national contestation strategies.

This article attempts to fill this research gap by analysing the contestation of RtoP undertaken by two important regional players, namely Brazil and Russia. The choice of these two particular countries is guided by the fact that both have expressed willingness to take on increasing responsibilities in global governance and share the ambition to participate in the reform of the international order. Moreover, both countries have traditionally stressed the primacy of state sovereignty and the non-intervention principle as bedrocks of international relations. However, in spite of these similarities, Brazil and Russia have demonstrated varied degrees of acceptance of RtoP. In fact, Russia has objected to the implementation of the coercive dimension of the principle by conflating it with forcible humanitarian intervention. Brazil, in turn, notwithstanding its long-standing reservations regarding the use of force, has assumed a more nuanced stance, by proposing the principle of 'Responsibility while Protecting' ( $\mathrm{RwP}$ ) as a contribution to the RtoP's doctrine.

To understand the main drivers of contestation, we will focus on differing foreign policy concerns, identities, and self-perceptions of Brazil and Russia. This comparative assessment aims to examine how aspirations of a more influential international role have been translated into normative reframing. For this purpose, the framework of norm dynamics role-spectrum proposed by Bloomfield (2016), will serve as an analytical point of departure.

Instead of considering all RtoP dissenter states as equal in the extent of their resistance, Bloomfield distinguishes between different roles that they may play. Hence, he proposes a continuous model of resistance, which amounts to the so-called norm dynamics role-spectrum, where the extremes correspond to diametrically opposite categories. The latter are the norm antipreneurs, who defend the normative status quo and resist relentlessly to changes, and the norm entrepreneurs, who support the norm without reservations (Bloomfield 2016, 330-31). Furthermore, there are intermediate positions, notably the creative resisters and competitor entrepreneurs. The creative resisters correspond to antipreneurs who yield some ground for the norm while substantially retaining their belief in the validity of the pre-existing normative frameworks. The competitor entrepreneurs are actors who share the same basic normative understandings of entrepreneurs, but differ on the exact scope and content of the new norm (Bloomfield 2016).

Our analysis will begin in 2001, a year which has witnessed the first formulation of the RtoP principle by the ICISS report, and it will end in 2016, a year which brought about major challenges for both Brazil and Russia. On the Brazilian side, the controversial impeachment 
of President Dilma Rousseff on $31^{\text {st }}$ of August 2016 represented the end of a political cycle characterised by an unprecedented foreign policy activism. Notwithstanding the inclination to turn inwards during Dilma Rousseff's presidency, particularly during her second mandate due to the worsening internal economic and social situation (Cervo and Lessa 2014), some degree of remaining diplomatic entrepreneurship has been translated into an active participation in the UN intervention debates. On the Russian side, this year witnessed the crystallisation of the status of Crimea as part of the Russian Federation and the gradual 'freezing' of the conflict in Eastern Ukraine. These two developments are of critical importance for the assessment of various aspects of Russian foreign policy, including those related to RtoP.

In order to outline Brazilian and Russian motivations to engage in debates over RtoP, the first two sections of this article will outline their international aspirations as reflected in the major tenets of respective foreign policies, and assess the reactions of both countries to RtoP. In the third section, dedicated to the cross-case comparison, we will apply the framework of norm dynamics role-spectrum proposed by Bloomfield in order to identify the different rationales behind RtoP contestation. The work concludes that while Russia, in its condition of permanent member of the United Nations Security Council (UNSC), has been able to more openly oppose RtoP through 'norm antipreneurship', Brazil, in its pursuit of gaining that exclusive status, has felt impelled to make a contribution to the RtoP doctrine based on the concept of Responsibility while Protecting. In doing so, the country has exhibited a stance that can be described as contesting entrepreneurship.

\section{Becoming a 'Responsible Stakeholder': Brazil's Evolution From Non-Indifference to Responsibility while Protecting}

Since the presidency of Lula da Silva (2003-2010), Brazil's quest for global influence has been advanced with special determination. As the country has developed to become the seventh largest world economy, it was believed that Brazil could aspire to a leadership role at the global level (Ferreira-Pereira 2016, 63). This perception of Brazilian authorities has been substantiated through an "active and self-confident" foreign policy (Amorim 2010), whose ultimate ambition was the democratisation of the global order. Through the strategy of "autonomy through diversification", several efforts have been made to redefine Brazil's role in the international arena, such as the promotion of an enhanced South-South cooperation, increased presence in different multilateral arrangements (e.g. MERCOSUL-EU (Mercado Comum do Sul-European Union; South Africa, India and China (BASIC)), the creation of new fora (e.g. India-Brazil-South Africa (IBSA)), The Group of Twenty (G20), and the country's candidacy for a permanent seat in the UNSC (Ferreira-Pereira 2016; Vigevani and Cepaluni, 2012). Consequently, Brazil's evolving global actorness has been translated into willingness to take greater responsibilities on the international stage, including in the realm of international security (Ferreira-Pereira 2016, 62). 
Brazil's official position regarding peacekeeping operations has been informed by the country's constitutional principle of non-intervention. As a result of a historical experience marked by almost two centuries of a continued US and European interventionism, Brazil places paramount importance upon the rule of non-intervention as a safeguard of sovereign autonomy and the boundaries of the rule of international law (Tourinho 2015,80). On the other hand, considering the endemic levels of domestic violence rooted on pervasive social inequalities, the country has been very cautious when it comes to humanitarian interventions, thereby privileging "justice among rather than within nations" (Kenkel 2013, 96). In this sense, even though Brasília has been a "consistent and committed contributor" to UN international peacekeeping, its participation has been limited to operations authorised exclusively under Chapter VI of the UN Charter (Kenkel 2013, 98). Nevertheless, as the country's aspiration to international prominence grew stronger, this position has started to change. In 2004, Brazil assumed a leading role in the UN Stabilisation Mission in Haiti (MINUSTAH), a multidimensional operation with an inherent peace enforcement component. This decision was meant as a demonstration of the country's commitment and capacity to shoulder increased responsibilities for international peace and security (Ferreira-Pereira 2016, 64). The ideological turn that made this possible consisted in the adoption of the principle of 'non-indifference', which has implied a posture of 'active solidarity' in crisis situations, deemed to be applied only to cases when the country's action was explicitly requested (Amorim 2003; Hermann 2011).

Ultimately, MINUSTAH served as a testing ground for a 'Brazilian way' of approaching peacekeeping operations. From the outset, this mission has been characterised by a unique combination of traditional security-oriented activities with more long-term strategies aimed at promoting the economic and social development - something that has enabled Brazil to capitalise on its expertise in security-development nexus. The added value of the Brazilian approach should be linked to the country's successful domestic experience regarding development initiatives, as well as pacification strategies in managing urban violence (Aguilar 2012, 218). From this perspective, the 'Brazilian way' to peacekeeping dynamics represents a diplomatic niche for the country's evolving global actorness, allowing it to 'punch above its weight' (Kenkel 2013). Although under the presidency of Dilma Rousseff (2011-2016) the political dynamism of Lula's years has lost some of its impetus (Cervo and Lessa 2014; Ferreira-Pereira 2016, 63), a certain degree of diplomatic entrepreneurship has been retained. This could be seen particularly in Brazil's endeavours to frame the discussions on RtoP to being more aligned with the country's own values.

\section{Brazil and RtoP: From Non-Indifference to Responsibility while Protecting}

Notwithstanding the initial dismissal of RtoP as "droit d'ingérence [...] in new clothes" (Amorim 2004), during the follow-up to the 2005 World Summit, Brazil expressed its support for the UN Secretary-General Kofi Annan's view of human security - as comprising both 'freedom 
from want' and 'freedom from fear' - that pervaded the principle. As the Brazilian Representative, Ronaldo Mota Sardenberg, made clear, "the ideals of development, security and human rights" should be addressed "in a concerted, forward-looking manner" (Permanent Mission of Brazil to the United Nations 2005). Therefore, while accepting that RtoP was worthy of attention, the Brazilian diplomatic discourse has recurrently questioned the means chosen to pursue its objectives, particularly the utility of using force.

As the principle became entrenched in the diplomatic practice of the UN, the official Brazilian discourse started to change towards a more supportive rhetoric, which lead to a more active participation in UN intervention debates ${ }^{2}$ (Kenkel 2015). A larger room of conceptual manoeuvre was provided by the implementation strategy based on three pillars introduced in 2009. Whereas the first pillar underlined the primary responsibility of a state to protect its population, the second stressed the duty of the international community to assist it in fulfilling its own responsibilities through national capacity-building. The third pillar related to the remedial responsibility of the international community to react when a state was unable or unwilling to protect its population. Such three-pillared division has enabled Brazil to emphasise its support for the prevention and state capacity-building through the endorsement of the first two pillars ${ }^{3}$. Conversely, the third pillar was referred to by the Brazilian authorities as being "subsidiary" and "a truly exceptional course of action" (Permanent Mission of Brazil to the United Nations 2009).

The year of 2011 was decisive for both the development of RtoP and Brazilian normative activism. After an initial period of exaltation over the 'coming of age' of RtoP, the manner in which the mandate to protect civilians came to be carried out in Libya has led to a great wave of condemnation, and has cast serious doubts about the legitimacy of using force to uphold RtoP; even when this was authorised by the UNSC. While the original mandate of the Resolution 1.973 of 17 March 2011 called for the establishment of a no-fly zone over Libya in order to protect civilians (United Nations Security Council 2011, 2), its operationalisation through NATO-led intervention has ultimately pursued Gaddafi's overthrow as the end goal. In the face of this expedient abuse of the UNSC mandate, Brazil's Permanent Representative, Maria Luiza Ribeiro Viotti, cautioned for the need of accountability measures and underlined that " $t \mathrm{t}]$ he use of force to protect civilians does not abrogate international law" (Permanent Mission of Brazil to the United Nations 2011a). This criticism was taken further by President Rousseff during her speech at the $66^{\text {th }}$ UN General Assembly, on 21 September 2011. Besides emphasising the "painful consequences of interventions", President Rousseff raised deeper controversy over whether force can protect (Rousseff 2011). In early 2013, when the Tuaregs militias, heavily armed after their service in Gaddafi's army, joined the jihadist groups in a coup d'état in Mali, these concerns over destabilising spill-over effects have indeed been confirmed. As a result, France launched a military intervention in January 2013 with the mandate to restore the Malian sovereignty. In this context,

2 Particularly since 2009, Brazil has been present in every Informal Interactive Dialogue at the General Assembly on RtoP, as well as an active participant in the UNSC Open Debates on Civilian Protection in Armed Conflict.

3 For more information on how the three pillars of RtoP have been internalised by Brazil, see Kenkel 2012; Stuenkel, and Tourinho (2014). 
President Rousseff reiterated the Brazilian reservations over the use of force, underlining that "the fight against terrorism should not justify neo-colonial temptations" (Rousseff 2013). This pointed to a prevailing tension springing from diverging interpretations of both the principle of non-intervention and the limits of the RtoP concept (Ferreira-Pereira 2016, 65).

It was against this background that Brazil started to promote the notion of "responsibility in protecting" (Rousseff 2011), which came to develop into a concept note on Responsibility while Protecting (RwP), launched in November 2011. At the core of RwP is the call for more responsible interventions, while advocating for the commitment to negotiation and conflict prevention. To avoid the misuse of protection mandates, RwP suggests that certain guidelines prior to the authorisation of the use of force by the UNSC (encompassing last resort, proportionality, and balance of consequences ${ }^{4}$ ) should be upheld (Permanent Mission of Brazil to the United Nations 2011 b, $\$ 5 ; 7)$. By the same token, it further underlines the need of adopting monitoring mechanisms to ensure the appropriate interpretation and implementation of UNSC resolutions (Permanent Mission of Brazil to the United Nations 2011b, $\$ 11 \mathrm{~h}-\mathrm{i})$.

Initial reactions to RwP were quite negative. Some key Western states, particularly the US, UK, and Germany, saw RwP as "nothing more than a procedural roadblock" (Welsh et al. 2013). The most controversial aspect of RwP was the Brazilian call for the adoption of "strict line of political subordination and chronological sequencing” of RtoP's three pillars (Permanent Mission of Brazil to the United Nations $2011 \mathrm{~b}, \$ 6$ ). This proposal was widely rejected by some NATO states' representatives due to its perceived rationale for inaction and ineffectiveness (Welsh et al. 2013). In light of this strong criticism, the sequencing proposed by Brazil was redefined towards a more logical expression, now aimed to avoid "automatic linkages between the protection of civilians and the use of force" (Permanent Mission of Brazil to the United Nations, 2012). On the other hand, the initial scepticism towards the Brazilian proposal underlying RwP also included some lukewarm reactions from its BRICS counterparts. In particular, Russia and China, who represented the two most vocal critics of RtoP, remained cautious of RwP since it included the possibility of military action in "exceptional circumstances" authorised by the General Assembly in line with "Uniting for Peace" procedure, thus allowing to bypass the UNSC (Permanent Mission of Brazil to the United Nations, 2011b, \$11c). Nevertheless, in the sequence of Brazil's opposition to the intervention in Syria, some of these concerns have dissipated. For example, Russia has later referred to the "timeliness" nature of RwP (Permanent Mission of Russia to the United Nations, 2012).

The interest generated by the RwP principle has prompted expectations as regards its further development (Welsh et al, 2013), both in terms of politico-diplomatic debate and conceptual design. However, in August 2012, the Minister of Foreign Affairs, Antonio de Aguiar Patriota, stated that the main rationale behind RwP was not to impose a solution, but rather to foster a more inclusive debate and rebuild consensus around RtoP (Almeida 2013, 18). Although since then no

4 These criteria are not new and have been already contemplated in the ICISS report. They serve as precautionary principles to ensure that military power is exercised in a responsible way. 
conceptual clarification on the principle was ever issued, RwP has reverberated in the international discourse on RtoP for some time. It became a reference in several multilateral declarations, such as the Lima Declaration (South American-Arab Countries 2012, $\$ 2.43)^{5}$ and the Montevideo Declaration (ZOPACAS 2013, $\$ 41)^{6}$ and was inserted onto the UN agenda through an explicit reference in the July 2012 report of the Secretary-General.

However, due to the decline of diplomatic commitment demonstrated by the Brazilian authorities in the remaining years of the first presidential mandate of Dilma Rousseff and, especially, during her second mandate, the relevance of RwP has faded away. In fact, references to RwP in the Brazilian statements have gradually decreased, and, as of the end of 2016, it appears that the principle is no longer part of the country's diplomatic glossary in the UN debates. Kenkel and Stefan $(2016,50)$ argue that a conflation of several factors contributed to this apparent 'retreat'. As these observers noted, much of the country's RwP-related momentum as an active player in the UN debates was favoured by the personal interest of Antonio de Aguiar Patriota. The development of RwP has benefited significantly from his advocacy and, therefore, his stepping down from the position of Minister of Foreign Affairs in August of 2013 has compromised the Brazilian normative entrepreneurship. Due to these changes within the Ministry of Foreign Affairs alongside the low priority ascribed to foreign policy-related matters by the President Rousseff (Ferreira-Pereira 2016, 63), the degree of Brazilian political activism has started to decrease. Incidentally, particularly as of the beginning of President Rousseff's second term (2015-2016), most of the governmental efforts came to be diverted to more pressing domestic issues. This inclination to turn inwards (Cervo and Lessa 2014) combined with a more 'reactive', rather than 'proactive' diplomacy (Cornetet 2014), have ultimately resulted in the erosion of the RwP principle in the Brazilian foreign policy discourse. Eventually, Brazil's withdrawal from sponsoring RwP at the UN level left the principle without the necessary diplomatic capital to survive in the highly-competitive international processes of normative production (Kenkel and Stefan 2016).

\section{Russia's Growing Resistance to the Liberal Order: the Case of Responsibility to Protect}

After the disintegration of the USSR in December 1991, the New Russia has found itself at the periphery of world politics. Notwithstanding the precipitous decline of its influence, in Moscow's perception, the country has remained "one of the largest world powers" (Melville and Shakleina 2005, 28). Therefore, since its independence, the Russian foreign policy has come to

5 The Declaration was endorsed by the members of the Arab and South American States in October 2012. It stated that RwP should be discussed at the UN, as well as within the Union of South American Nations (UNASUR) and the Arab League.

6 The Declaration was subscribed by members of the South Atlantic Peace and Cooperation Zone (ZOPAC) in January 2013. It recognized the importance of RwP and expressed the willingness to discuss the issue further. 
be driven by Kremlin's yearning "to achieve the equal and natural incorporation [...] into the world community as a great power" (Melville and Shakleina 2005, 27). The quest for international recognition of Russia's status in world politics came to be undertaken with special resolve since 2000, under the presidency of Vladimir Putin.

During the last year of President Putin's second term, Russian diplomatic discourse and practice came to exhibit contours of increased assertiveness. At the Munich Conference on Security Policy held in February 2007, President Putin's speech was extremely critical of the US unilateralism, characterised by "the hyper use of force", disrespect for international law and imposition of its policies on other nations ${ }^{7}$ (Putin 2007). At the same time, he drew attention to the changing world order and the need for greater democratisation of international affairs (Putin 2007). The speech served to send a strong message on the kind of treatment that Kremlin was expecting from the West - "accept us as we are, treat us as equals, and establish cooperation based on mutual interests” (Trenin 2009, 142).

Accordingly, Russia's 'near abroad' corresponding to the post-Soviet space has been acknowledged as the region of its "privileged interests" (Medvedev, 2008a). The first warning sign of Russia's assertiveness became evident in Kremlin's reaction to the coloured revolutions in this region, which were perceived in Moscow as being 'politically engineered' and devoid of legitimacy (Tsygankov 2016, 178). To diminish their influence, Russia has even resorted to more coercive measures such as commercial embargoes on Moldova and Georgia, or threats to cut off natural gas deliveries to Ukraine. Yet, the 2008 Russia-Georgian Five Day Way ${ }^{8}$ which followed the proclamation of Georgia's goal to adhere to the EU and NATO was a real turning point in Russian international behaviour. The Russian extensive intervention was characterised by many observers as an indication of Moscow's increasing willingness to resort to military force in order to uphold its influence (Lo 2015). The subsequent recognition of South Ossetia and Abkhazia as independent states has signalled a denunciation of the principle of respecting the territorial integrity of the post-Soviet states. After all, no other secessionist regions like Transdnistria and Nagorno-Karabakh had ever received such a political support from Moscow.

As of 2012, Russian foreign and security policies became even more assertive. By the time Putin started his third presidential term (2013-2018), the Russian political discourse witnessed a 'civilizational turn' (Tsygankov 2016, 233). Moscow has started to position itself as a unique "state-civilization" (Putin 2013), pointing to the country's distinctiveness and cultural self-standing (Lo 2015). This civilizational language translates Russia's resistance to the alleged universalism of

\footnotetext{
7 The most emblematic demonstration of disdain for international law was the US intervention in Iraq, in 2003. Nevertheless, alleged instigation of coloured revolutions in the former Soviet region, NATO's eastward expansion and plans to deploy elements of a US global missile defence system in Eastern Europe also represented examples of how US “overstepped its national borders" (Putin 2007).

8 The Georgian military offensive on Tskhinvali on 7th August intended to 'restore constitutional order' in South Ossetia resulted in deaths of civilians and Russian peacekeepers (exact number of victims is unknown). Russia responded by sending a large number of troops to the region under the claim of legitimate self-defence under Chapter 51 of the UN Charter, supported by bombings. However, after Georgian forces were expelled from the enclave, Russian troops further dispersed through Georgian territory (away from areas before patrolled by Russian peacekeepers) and destroyed important military infrastructure. Additionally, Russian military actions in Abkhazia were preventive in nature, which demonstrated the disproportionality of Russian response.
} 
Western-led liberal values. Importantly, the 2013 Foreign Policy Concept describes the world in terms of "rivalry of values and development models" (Russian Federation 2013, \$13). It further underlines the transition of the world order to a polycentric configuration, in which "[n]ew centres of economic growth and political power increasingly take responsibility for their respective regions" (Russian Federation 2013, \$19). In this sense, as one of the 'civilizational poles', Russia positions itself as "a leader and centre of gravity for the whole of Eurasia" (Putin 2012). This self-assigned role is encapsulated in the establishment of the Eurasian Economic Union in January 2015 (Vieira 2016) and signals a new rationale for Russia's regional hegemony.

After the Russian intervention in Georgia, another radical departure from its previous policies in the region consisted in its annexation of Crimea in March 2014, which followed the deterioration of relations with Ukraine? (Allison 2014). Although Russian authorities insisted that "Russia did not annex Crimea by force", they acknowledged that "Russia created conditions - with the help of special armed groups and the Armed Forces [...] - but only for the free expression of the will of the people living in Crimea and Sevastopol" (Putin 2014a). President Putin made it clear that, if necessary, the use of Russian military would be undertaken in a legitimate way, as the ousted Ukrainian President Viktor Yanukovych requested Russian intervention to restore law and order in the country (Putin, 2014b). This 'quiet' takeover of the peninsula has revealed Kremlin's capacity to wage non-linear war, in the context of which open or covert military operations are complemented by the use of political and economic state instruments, secret services, and information wars (Sakwa et al. 2015). Moreover, and more importantly, the annexation of Crimea into the Russian Federation has constituted an unprecedented territorial development, to the extent that no other breakaway regions, including Abkhazia and South Ossetia, had ever signed the accession agreements.

In the months following the Crimean annexation until today, Russia has denied any involvement in the Eastern part of Ukraine, where pro-Russian separatists have established the self-proclaimed republics in Luhansk and Donetsk corresponding to the newly launched geopolitical construct of Novorossiya ('New Russia'). In this case, Moscow has not invoked any legal argument to justify its presence in the region, for officially speaking there is none. Instead, Moscow has accused the Ukrainian governmental authorities of violating international law when conducting their military operations (Permanent Mission of Russia to the United Nations, 2014), something which has showed Kiev's failure in protecting its own population. Given that the Russian political rhetoric to legitimatise intervention both in Georgia and Ukraine invoked RtoP-related arguments, these two cases are critical for the assessment of the country's stance on the principle.

9 The train of events that followed former Ukrainian President Viktor Yanukovych's decision in November 2013 to back away from Ukraine's Association Agreement with the EU unexpectedly led to a crisis that put the country on the verge of fragmentation. Massive waves of protests, hailed as Euromaidan, filled the streets of Kiev and other Ukrainian cities. What started out as peaceful demonstrations soon escalated into violent confrontations between the protestors and the riot police. Subsequent ousting of Yanukovych was followed by the Crimea's unilateral referendum on secession on March 16, which was organized in contravention of Ukraine's constitution and under extensive military presence. 


\section{Russia and RtoP: From Tolerance to Contestation}

At the 2005 World Summit, Russia endorsed RtoP, but not without reservations. As the then Permanent Representative of Russia to the UN, Andrey Denisov, noted, the concept was lacking the needed wide support within the international community to be recognised as an international norm (Permanent Mission of Russia to the United Nations 2005). Yet, he still admitted that "massive human rights violations and genocide could be a cause for intervention", if only authorised by the UNSC and in strict compliance with the UN Charter (Permanent Mission of Russia to the United Nations 2005). In 2009, at a UN General Assembly Plenary, the Russian representative Mikhail Margelov pointed out that the protection of people from the four heinous crimes was "one of the most important issues of our time" (Permanent Mission of Russia to the United Nations 2009). Nevertheless, he insisted on the literal reading of the original formulation of RtoP as basis for its implementation, thus prioritising Russia's commitment to the first two pillars of the principle, and evincing its commitment to sovereignty understood as state responsibility to provide security and order within its borders ${ }^{10}$.

As such, from 2005 up to 2011, Moscow has demonstrated cautious support to RtoP. In a landmark moment for the principle which was the UN discussions on intervention in Libya, Russia abstained from the use of veto on the Resolution 1973, thereby enabling the enactment of RtoP's third pillar in Libya. However, as the NATO-led air campaign to enforce the no-fly zone unfolded, Moscow has expressed its concerns over the disproportionate use of force and pleaded for caution (Medvedev 2011). Harsher criticism was expressed by the then Prime Minister Putin, who stated that the resolution was reminiscent of "medieval calls for crusades" (Putin, 201111, cited by Bryanski 2011). Alongside Russian protests against twisted interpretation of the resolution, the West was accused of hypocrisy and the practice of all-permissiveness (Kurowska 2014, 501). Consequently, Russia has recurrently underlined the malleability of RtoP to expedient abuse. In 2016, Russian authorities considered the RtoP principle incipient and believed that further discussions in the General Assembly continued to be in order (Permanent Mission of Russia to the United Nations, 2016).

Along these lines, Russia has been extremely critical of the attempts to launch 'Libyan-style' military intervention in Syria for equating it to the "partisan intercession in a civil war" (Kurowska 2014, 501). Over the last four years, Moscow has vetoed four resolutions ${ }^{12}$ on the Syrian conflict, arguing that Western powers have been exploiting the principle of humanitarian intervention in

10 For more information on how the three pillars of RtoP have been internalised by Russia, see Kuhrt (2014).

11 [Путин: резолюция СБ ООН по Ливии ущербна, напоминает крестовый поход] (March 21, 2011). RT. Available at: https:// russian.rt.com/inotv/2011-03-21/Putin-osudil-krestovij-pohod-Zapada. Accessed February 5, 2018.

12 The resolution in May 2014 sought to refer Syria to the International Criminal Court, the July 2012 proposal would have threatened the possibility of sanctions on Syria if violence continued and the February 2012 proposal was a peace plan to stop violence in the country, at a time when the conflict was less than a year old. Though it is beyond the temporal scope of our analysis, it has to be mentioned that as for the late 2016, Russia has vetoed two more draft resolutions on Syria in the months of October and December, while claiming they misrepresented the complex realities on the ground. 
order to advance their own interests. Furthermore, the country has insisted on a political solution to the crisis in full accordance to the international law. As a party to peace negotiations, the country positions itself as a 'reliable' and neutral actor, claiming to be the only power who met with all the parties to the conflict (Lavrov 2013). Moscow's successful negotiation of the removal of chemical weapons in 2013 and its military operation in Syria launched in September 2015 upon the request of President Assad have further contributed to reinforce this self-perception.

Nevertheless, Russia’s firm stance against an intervention in Syria stands in stark contrast with its engagement in conflicts in its strategic neighbourhood. Alongside claims for legitimate self-defence, accusations of "genocide" (Medvedev 2008b) and "crimes of war" committed by Georgian soldiers (Lavrov 2008) have been advanced to justify Russia's military action in the Georgian territory in 2008. By the same token, a "looming humanitarian catastrophe" (Allison 2014, 1264) has served as a pretext for coercive interference in Ukraine in 2014, which has culminated with the annexation of Crimea in March of that year. More importantly, in both cases the country's 'duty to react' was grounded on its constitutional right to "[guarantee] its citizens defence and patronage beyond its boundaries" (Russia Federation 1993, Article 61 (2)) As the Foreign Minister Lavrov stated back in 2008, Russian actions in Georgia proved that the "country has returned onto the world stage as a responsible state that has the ability to defend international law and its citizens" (Lavrov 2008). In the same vein, with reference to the annexation of Crimea, he emphasised that "[it was] all about the protection of [Russian] citizens and compatriots, defending the most fundamental human right - the right to live" (Lavrov 2014). The meaning-in-use of 'responsibility' behind these statements highlights the primary responsibility of a kin-state towards its nationals.

In this sense, Russia's kin state responsibilities towards its (co)citizens abroad have been substantiated by different strategies, with the policy of 'passportization' conducted in Ossetia and South Abkhazia prior to August 2008 being the most important one. ${ }^{13}$ While no overt passportization took place in Crimea, the referendum realized in March 2014 ended up equating Russia's compatriots to citizens, ultimately blurring the line between the two categories. "The misuse of RtoP in both cases can be seen as resulting from an alternative reading of the concept's first pillar, substantiated on the Russian state-centric vision of security. Accordingly, the emphasis was placed on Russia's responsibility as a security guarantor to protect its citizens/compatriots. The extension of this responsibility beyond its borders in the cases of Georgia and Ukraine was possible because, as the states are located in Russia's area of 'privileged interests', their sovereignty is perceived in relative terms (Lo 2015, 96).

However, as Russian non-intervention in Kyrgyzstan in 2010 showed, the likelihood of Moscow's direct interference in its backyard is not a given. Despite the call for intervention made by the Kyrgyz authorities, Moscow has depicted the crisis as an internal matter and has rather focused on relief measures and humanitarian assistance (Matveeva 2013, 486). The ambiguity of

13 For a detailed assessment of the policy of 'passportization', see consult Independent International Fact-Finding Mission on the Conflict in Georgia (IIFFM 2009, 18).; Green (2010). 
the Russian position is influenced by contradictions inherent to the complex arrays of interests which shape its actions in the 'near abroad' (Davies 2016). Accordingly, the framing of Russian actions as 'Russian responsibility' towards its citizens/compatriots, as it was the case in Georgia and Ukraine, does not ensure RtoP's incorporation in the Russian strategy towards its own regional sphere of influence.

\section{Brazil and Russia: Different Normative Roles in Approaching Responsibility to Protect}

Albeit sharing the stalwart belief in the primacy of both state sovereignty and the principle of non-intervention, Brazil and Russia have adopted different approaches regarding RtoP. Interestingly, up until 2011 their discourses have followed similar lines which pointed to a limited acceptance of the principle. It was after the intervention in Libya that their positions have started to diverge considerably. Moscow seized NATO's overstretch of the UN mandate to highlight the malleability of RtoP and has consequently been acting as a "loud dissenter" (Snetkov and Lanteigne 2015). As for Brazil, it came to assume a more constructive position in calling for more responsible military interventions through the advancement of RwP, while reiterating its reservations when criticising the French intervention in Mali.

Both Brazilian and Russian contestation discourses have focused on issues of substance by questioning in which relevant situations RtoP should be applied, and what precise actions its application entail. However, Russian contestation has been aimed at limiting the scope of RtoP, whereas the Brazilian one has reflected an effort to build broader support for the principle. In the light of the main tenets of the two countries' foreign policies, it can be argued that different levels of acceptance of RtoP result from varying degrees of congruence between the principle and their longstanding domestic values and international aspirations. In this sense, divergent reactions to RtoP should be understood against the backdrop of the evolving international identities of both countries, particularly of the roles that they assign to themselves in the emerging global order.

Accordingly, in its pursuit of permanent membership in the UNSC, Brazil has attempted to play the role of a valid interlocutor while capitalising on its consensus-seeking skills. In a demonstration of its commitment to the UN cause, instead of directly counter-attacking RtoP, Brasília has advanced a complementary principle that is the RwP. In advocating the establishment of precautionary principles prior to the authorisation of the use of force, RwP has attempted to raise the bar for armed interventions. Moreover, given the lessons learnt from Libya, the new principle called for the adoption of monitoring mechanisms and accountability measures, based on the argument that interveners should be held responsible for their actions. As the RwP was conceived to evolve alongside RtoP, Brazilian normative activism fell short of the classical examples of entrepreneurship. Instead of norm making, it has rather represented an example of normative subsidiarity (Kenkel and Rosa 2015). Through the RwP proposal, Brazil has intended 
to separate two trends of International Humanitarian Law, namely the protection of civilians and the use of force in military operations (Serbin and Serbin Pont 2015), while projecting the national preference for the security-development nexus into RtoP. This has showed that Brasília's main reservations with RtoP were not related to the idea of responsible protection, but instead pertain to the hegemonic manner of norm implementation, which treats military force as the arbitrator of justice and the promotion of peace (Patriota 2011). Hence, normative resistance to RtoP reflects broader concerns about the purpose of multilateralism and the importance of a rule-based international order that treats states as equals (Tourinho 2015, 91).

When assessing Brazil's normative activism, Bloomfield assigned the country a role of competitor entrepreneur (Bloomfield 2016, 329). However, as a result of the assessment of Brazil's reactions to RtoP in light of the main features of the country's international identity, we argue that, while yielding some ground to RtoP, Brasília's contesting behaviour also reveals some aspects of creative resistance. In fact, notwithstanding its adoption of the notion of 'non-indifference', this posture of 'active solidarity' in crisis situations was limited to cases when the country's action was requested and where it could make a positive impact (Hermann 2011). The advent of Dilma Rousseff's presidency, characterised by a more explicit defence of the human rights agenda (Jesus, 2014), did not change the country's stance regarding intrusive norms of humanitarian intervention. Alongside the practice of norm subsidiarity, the distinctive elements of resistance, such as the long-standing aversion to the use of force as a means to promoting peace, should be taken into consideration. Therefore, the Brazilian approach to RtoP is better described as an example of contesting entrepreneurship. Hence, we proposed the introduction of an additional category in the norm dynamics role-spectrum that corresponds to a middle-ground between creative resistance, and competitor entrepreneurship (Figure 1).

As for Russia, its attitude towards RtoP is clearly an example of norm antipreneurship. The Russian stance over Syria presents a telling example of the country's discursive and institutional resistance. The country has resorted to its veto power to block various UN resolutions regarding the imposition of sanctions on the Syrian government over continued violence perpetrated on its population or its referral to the International Criminal Court. Moreover, it has pointed towards the Libyan precarious post-conflict reality as an example of how interventions under RtoP tend to further exacerbate insecurities.

That being said, Russia's opposition to RtoP has showed that there always are exceptions to the rule. When its national interests coincided with provisions of the principle, Moscow has utilised RtoP to justify its foreign policy actions. These were the cases of Russian intervention in Georgia in 2008 and the annexation of Crimea in 2014. In both episodes, Russian legitimation discourse can be decomposed into two separate narratives: one directed internationally, and another one addressed to its domestic audience. Regarding the internationally-oriented narrative, an emphasis was placed on the legality of Moscow's actions. As such, humanitarian rhetoric was complemented with arguments of self-defence (e.g. Georgia) and the request of the allegedly legitimate President to uphold peace (e.g. Ukraine). These efforts to justify military involvement 
in the light of international law only prove that Moscow is concerned about its international image. As for the nationally-oriented narrative, references to genocide, crimes of war, and humanitarian crises were secondary to the main claim of Russia's constitutional right to protect its citizens and compatriots. As Snetkov and Lanteigne $(2015,122)$ have noted, Russia perceives RtoP primarily as an institutionalised principle within the UN, rather than a fundamental change in the understanding of sovereignty. In fact, the framing of responsibility from the perspective of a kin-state reveals an alternative reading of the RtoP's first pillar. Ultimately, as non-intervention in Kyrgyzstan has demonstrated, this selective misuse of RtoP is done on an ad hoc basis, in the sequence of a pragmatic assessment of a given conflict, thus, in the absence of an overarching strategy.



Source: Adapted from Bloomfield 2016, 331

Figure. 1 Brazil and Russia on the norm dynamics role-spectrum

\section{Conclusion}

Through the comparative analysis of two high-dissenter states, this article has attempted to identify the reasons that explain the divergent forms of normative resistance adopted by Brazil and Russia vis-à-vis the RtoP. Based on the theoretical framework offered by Bloomfield, the ambiguous position of Russia regarding RtoP is explained through the notion of norm antipreneurship. We argue that, in spite of endorsing the principle in 2005, Russia has retained a state-centric approach to security. Besides its insistence on the literal reading of the original formulation in the Summit Outcome Document, the use of RtoP rhetoric to justify its intervention in Georgia and Ukraine serves to confirm this assumption. In its deviation from the main tenets of RtoP, which is the remedial responsibility to protect people in distress, the resort to the constitutional right to protect Russian citizens and compatriots reveals that the Russian view of the principle mainly was informed by the responsibility of a kin-state towards its nationals.

As for Brazil, notwithstanding its practice of subsidiary through the advancement of RwP to strengthen RtoP, the degree of normative resistance to the latter principle should not be 
underestimated. On the other hand, Brazil's contribution to the RtoP doctrine, through the RWP proposal against the backdrop of its unswerving pursuit of a seat in the UNSC, has undoubtedly placed the country within the normative community of the entrepreneurs. However, due to its historical background, Brazil's international insertion has been driven by the quest for autonomy with anti-hegemonic traits. In this sense, although sharing the normative understandings of human security, the country continues to defend the status quo as far as the principle of non-intervention is concerned. Along these lines, we have characterised the role of Brazil as a contesting entrepreneur, thereby recognising the particularities of its contestation that were left unaccounted for by the Bloomfield's model categories of 'competitor entrepreneur' and 'creative resister'.

As the world is transitioning towards multipolarity, it becomes increasingly important to understand the positions of the (re)emerging powers on such sensitive issues like humanitarian intervention. This article has demonstrated that normative resistance to RtoP is much more than a simple opposition to the allegedly Western norm. Instead, it is informed by complex dynamics of cultural pluralism. The assessment of roles that (re)emerging powers, such as Brazil and Russia have adopted towards RtoP brings valuable insights on the main drivers of resistance and, ultimately, can be revealing of contours that the emerging multipolarity is acquiring.

\section{References}

Acharya, A. "The responsibility to protect and a theory of norm circulation."

In Theorising the Responsibility to Protect, edited by R. Thakur, and

W. Maley, 59-78. New York: Cambridge University Press, 2015.

doi: https://doi.org/10.1017/CBO9781139644518.004.

Aguilar, S. "Uma Cultura Brasileira de Missões de Paz." In Diplomacia Brasileira para a Paz, edited by C. Brigagão, and F. Fernandes, 215-43. Brasília, DF: FUNAG. 2012.

Allison, R. "Russian 'Deniable' Intervention in Ukraine: How and Why

Russia Broke the Rules.” International Affairs 90, no. 6 (2014): 1255-97.

doi: https://doi.org/10.1111/1468-2346.12170.

Almeida, P. W. “From Non-indifference to Responsibility While Protecting: Brazil's Diplomacy and the Search for Global Norms". SAAIIA Occasional Paper 138 (2013): 1-28. Accessed January 27, 2018. http://www.saiia.org.za/occasional-papers/from-nonindifference-to-responsibility-while-protecting-brazils-diplomacy-and-the-search-forglobal-norms

Amorim, C. 2003. Inaugural Speech of the Minister of Foreign Affairs. Brasília, D.F.: Itamaraty, 2003. Accessed January 29, 2018. http://www.itamaraty.gov.br/pt-BR/ discursos-artigos-e-entrevistas/ministro-das-relacoes-exteriores-discursos/7547-discursoproferido-pelo-embaixador-celso-amorim-por-ocasiao-da-transmissao-do-cargo-deministro-de-estado-das-relacoes-exteriores 
Amorim, C. 2004. Conceitos e Estratégias da Diplomacia do Governo Lula. Brasília, D.F.: Itamaraty, 2004. Accessed January 27, 2018. http://www.itamaraty.gov.br/pt-BR/pt-\%20 BR?option=com_content \&view=article\&id=7664:artigo-conceitos-e-estrategias-da-\%20 diplomacia-do-governo-lula\&catid=163\&lang=pt-br\&Itemid=196

Amorim, C. "Brazilian Foreign Policy under President Lula (2003-2010): An overview." Revista Brasileira de Politica Internacional 53, no. spe. (2010): 214-40.

Baranovsky, V, and A. Mateiko. "Responsibility to Protect: Russia’s Approaches." The International Spectator 51, no. 2 (2016): 49-69. doi: https://doi.org/10.1080/03932729.2016.1176648.

Bloomfield, A. "Norm Antipreneurs and Theorising Resistance to Normative

Change." Review of International Studies 42, no. 2 (2016): 310-33.

doi: https://doi.org/10.1017/S026021051500025X.

Bryanski, G. "Putin Likens U.N. Libya Resolution to Crusades.” Reuters, March 21, 2011.

Accessed February 4, 2018. https://www.reuters.com/article/us-libya-russia/putin-likensu-n-libya-resolution-to-crusades-idUSTRE72K3JR20110321

Cervo, A. L., and A. C. Lessa. "O declínio: inserção internacional do Brasil

(2011-2014)." Revista Brasileira de Politica Internacional 57, no. 2 (2014): 133-51. doi: http://dx.doi.org/10.1590/0034-7329201400308.

Davies, L. "Russia's 'Governance' Approach: Intervention and the Conflict in the Donbas". Europe-Asia Studies 68, no. 4 (2016): 726-49

Cornetet, J. M. C. "A política externa de Dilma Rousseff: contenção na continuidade.” Conjuntura Austral 5 no. 24 (2014): 111-50. doi: http://dx.doi.org/10.22456/2178-8839.47628.

Ferreira-Pereira, L. C. “The European Union's partnership policy towards brazil: more than meets the eye." Cambridge Review of International Affairs 29, no. 1 (2016): 55-77. doi: https://doi.org/10.1080/09557571.2015.1103973.

Finnemore, M., and K. Sikkink. "International Norm Dynamics and Political Change.” International Organization 52, no. 4 (1998): 887-917. doi: https://doi.org/10.1162/002081898550789.

"Foreign Policy Conception of The Russian Federation." In Russian Foreign Policy in Transition: Concepts and Realities, edited by A. Melville, and T. Shakleina, 27-64. Budapest: Central European Univeristy Press, 2005.

Garwood-Gowers, A. "The BRICS and the Responsibility to Protect: Lessons from the Libyan and Syrian Crises." In Responsibility to Protect in Theory and Practice, edited by V. Sancin, and M. K. Dine, 291-315. Ljubljana: GV Zalozba, 2013.

Green, J. "Passportisation, peacekeepers and proportionality: the Russian claim of the Protection of Nationals Abroad in self-defence." in Conflict in the Caucasus: Implications for International Legal Order, edited by J. Green, and C. Waters, Christopher, 54-79. New York, NY: Palgrave Macmillan, 2010.

Hermann, B. Soberania, não intervenção e não indiferença: reflexóes sobre o discurso diplomático brasileiro. Brasília, DF: FUNAG, 2011. 
Independent International Fact-Finding Mission. Independent International Fact-Finding Mission (IIFM) on the Conflict in Georgia: Report. [n.p.]: IIFM, 2009. vol. 2. Acessed February 5, 2018. http://www.mpil.de/files/pdf4/IIFFMCG_Volume_II1.pdf

Jesus, D. S. V. “The benign multipolarity: Brazilian foreign policy under Dilma Rousseff." Journal of International Relations and Foreign Policy 2 no. 1 (2014): 19-42.

Job, B. L., and A. Shesterinina. "China as a Global Norm-Shaper: Institutionalization and Implementation of the Responsibility to Protect". In Implementation and World Politics: How International Norms Change Practice, edited by A. Betts, 144-59. Orchard, PA.: Oxford University Press, 2014.

Kenkel, K. M. “Brazil and R2P: Does Taking Responsibility Mean Using Force?” Global Responsibility to Protect 4 no. 1 (2012): 5-32.

Kenkel, K. M. "Out of South America to the Globe: Brazil's Growing Stake in Peace Operations". In South America and Peace Operations: Coming of Age, edited by K. M. Kenkel, Kai Michael, 85-110. [n.p.]: Routledge, 2013.

Kenkel, K. M. "Interests, Identity and Brazilian Peacekeeping Policy". In Enduring NATO, Rising Brazil: Managing International Security in a Recalibrating Global Order, edited by B. Smith-Windsor, 83-115. [n.p.]: NATO Defence College, 2015.

Kenkel, K. M., and M. T. Martins. "Emerging Powers and the Notion of International Responsibility: Moral Duty or Shifting Goalpost?” Brazilian Political Science Review 10, no. 1 (2016): 1-27. doi: http://dx.doi.org/10.1590/1981-38212016000100003.

Kenkel, K. M., and F. Rosa. "Localization and Subsidiarity in Brazil's Engagement with the Responsibility to Protect." Global Responsibility to Protect 7, no. 3-4 (2015): 325-49. doi: http://dx.doi.org/10.1163/1875984X-00704006.

Kenkel, K. M., and C. G. Stefan. "Brazil and the Responsibility While Protecting Initiative: Norms and the Timing of Diplomatic Support." Global Governance 22, no. 1 (2016): 41-58. Kuhrt, N. "Russia, the Responsibility to Protect and Intervention." In The Responsibility to Protect and the Third Pillar: Legitimacy and Operationalization, edited by D. Fiott, and J. Koops, 97-114. Houndmills: Palgrave MacMillan, 2014.

Kurowska, X. "Multipolarity as resistance to liberal norms: Russia's position on responsibility to Protect." Conflict, Security \& Development 14, no. 4 (2014): 489-508. doi: https://doi.org/10.1080/14678802.2014.930589.

Lavrov, S. "Interview by Minister of Foreign Affairs of the Russian Federation Sergey Lavrov to BBC." August 9, 2008, Ministry of Foreign Affairs of the Russian Federation. Accessed January 30, 2018. http://www.mid.ru/web/guest/maps/ge/-/asset_publisher/ uwHHxf8KDaOY/content/id/328774

Lavrov, S. "Russian Foreign Policy Philosophy [Внешнеполитическая философия России]." International Life [Международнаяжизнь]. March 28, 2013. Accessed January 30, 2018. http://www.mid.ru/web/guest/foreign_policy/news/-/asset_publisher/ cKNonkJE02Bw/content/id/117070 
Lavrov, S. Statement of the Minister of Foreign Affairs at the High-Level Segment of the 25 Session of the UN Human Rights Council. Geneva: UN, 2014. Accessed January 30, 2018. http://www.humanrightsvoices.org/assets/attachments/documents/lavrov.pdf

Lo, B. Russia and the New World Disorder. Washington, D.C.: Brookings Institution Press; London: Chatham House, 2015.

Medvedev, D. Interview Given by President of Russia to Television Channels Channel One, Rossia, NTV. August 31, 2008a, 18:50, Sochi. Accessed January 29, 2018. http:// en.kremlin.ru/events/president/transcripts/48301

Medvedev, D. "President of Russia Dmitriy Medvedev Recognized the Independence of South Ossetia and Abkhazia.” RBK Agency, Augusy 26, 2008b. Accessed January 29, 2018. http://www.rbc.ru/politics/26/08/2008/5703ce849a79473dc81487d9

Medvedev, D. Statement by the President of Russia on the situation in Libya. March 21, 2011, 18:30. Accessed January 29, 2018. Accessed February 5, 2018. http://en.kremlin. $\mathrm{ru} /$ events/president/news/10701

Melville, A., and T. Shakleina. Russian Foreign Policy in Transition: Concepts and Realities. Budapest: Central European Univeristy Press, 2005.

Matveeva, A. "Russia's changing security role in Central Asia.” European Security 22, no. 4 (2013): 478-99. doi: https://doi.org/10.1080/09662839.2013.775121.

Patrick, S. "Irresponsible Stakeholders? The Difficulty of Integrating Rising Powers." Foreign Affairs, 89, no. 6 (2010): 44-53.

Patriota, A. A. 2011. "Direitos Humanos e ação diplomática.” Folha de S.Paulo, September 1, Tendências e Debates.

Permanent Mission of Brazil to the United Nations. "Statement at the $86^{\text {th }}$ Plenary Meeting of the General Assembly." Official Documents System of the United Nations. 2005. Accessed February 5, 2018. https://documents-dds-ny.un.org/doc/UNDOC/GEN/ N05/297/52/PDF/N0529752.pdf?OpenElement

Permanent Mission of Brazil to the United Nations. Remarks by H.E. Ambassador Maria Luiza Ribeiro Viotti, Permanent Representative of Brazil to the United Nations. July 23, 2009. Accessed February 5, 2018. http://www.globalr2p.org/media/files/brazil2009-r2p-debate.pdf

Permanent Mission of Brazil to the United Nations. Statement by H.E. Ambassador Maria Luiza Ribeiro Viotti Permanent Representative of Brazil to the United Nations Protection of Civilians in Armed Conflict. 10 May, 2011a. Accessed February 1, 2018. http://responsibilitytoprotect.org/brazil.pdf

Permanent Mission of Brazil to the United Nations. Letter dated 9 November 2011 from the Permanent Representative of Brazil to the United Nations addressed to the Secretary-General. November 11, 2011b. Accessed February 1, 2018. http:// www.globalr2p.org/media/files/concept-paper__rwp.pdf. Annex to the letter dated 9 November 2011 addressed to the Secretary-General. 
Permanent Mission of Brazil to the United Nations. Responsibility to Protect: Timelu and Decisive Response. September 5, 2012. Accessed February 5, 2018. http://www. globalr2p.org/media/files/brazil-statement-2012.pdf

Permanent Mission of Russia to the United Nations. $87^{\text {th }}$ Plenary Meeting of the General Assembly (A/59/PV.87). April 7, 2005, 10 a.m. Accessed February 5, 2018. http://dag. un.org/bitstream/handle/11176/253410/A_59_PV.87-EN.pdf? sequence $=3$ \&isAllowed $=y$

Permanent Mission of Russia to the United Nations. Letter dated 8 August 2008 from the Permanent Representative of Georgia to the United Nations addressed to the President of the Security Council. August 8, 2008. Accessed February 5, 2018. http://repository. un.org/handle/11176/11446

Permanent Mission of Russia to the United Nations. 2009. Statement of the Permanent Representative of the Russian Federation at the $100^{\text {th }}$ Plenary Meeting of the General Assembly (A/63/PV.100). Accessed February 5, 2018. http://responsibilitytoprotect.org/ RussianFederation(1).doc

Permanent Mission of Russia to the United Nations. Statement at the July 2009 GA Debate on RtoP (As Delivered). July, 2009a. Accessed February 5, 2018. http:// responsibilitytoprotect.org/RussianFederation(1).doc (accessed 5 February 2018)

Permanent Mission of Russia to the United Nations. 2009. Statement of the Permanent Representative of the Russian Federation at the 100th Plenary Meeting of the General Assembly (A/63/PV.100). Available at: http://responsibilitytoprotect.org/ RussianFederation(1).doc (accessed 5 February 2018)

Permanent Mission of Russia to the United Nations. Statement of the Representative of the Russian Federation at the General Assembly informal, interactive dialogue on the 'Responsibility to Protect: Timely and Decisive Response'. September 5, 2012. Accessed February 6, 2018. http://responsibilitytoprotect.org/Russia\%20Statement\%

Permanent Mission of Russia to the United Nations. 2014. 7165 $5^{\text {th }}$ Meeting of the United Nations Security Council. April 29, 2014, 5.55 p.m. Accessed February 5, 2018. http://www.securitycouncilreport.org/atf/cf/\%7B65BFCF9B-6D27-4E9C-8CD3CF6E4FF96FF9\%7D/s_pv_7165.pdf

Permanent Mission of Russia to the United Nations. 2016. Statement delivered at the Informal Interactive Dialogue on RtoP, 6 September 2016 [unofficial transcription from webcast]. Accessed February 1, 2018. http://www.globalr2p.org/media/files/russiastatement.pdf

Putin, V. Speech of the President of Russia at the Munich Conference on Security Policy. February 10, 2007, 01:38. Accessed February 1, 2018. http://en.kremlin.ru/events/ president/transcripts/24034

Putin, Vl. Vladimir Putin inaugurated as President of Russia. The inauguration ceremony took place in the Grand Kremlin Palace. May 7, 2012. Accessed February 1, 2018. http://en.kremlin.ru/events/president/news/15224 
Putin, V. Meeting of the Valdai International Discussion Club Vladimir Putin took part in the final plenary meeting of the Valdai International Discussion Club. The theme of the club's anniversary session is Russia's Diversity for the Modern World. September 19, 2013, 19:45. Accessed January 31, 2018. http://en.kremlin.ru/events/president/ news/19243

Putin, V. Vladimir Putin answered journalists' questions on the situation in Ukraine. March 4, 2014a, 15:40. Accessed January 31, 2018. http://en.kremlin.ru/events/president/ news/20366

Putin, V. Vladimir Putin submitted appeal to the Federation Council. March 1, 2014 b. Accessed January 31, 2018. http://en.kremlin.ru/events/president/news/20353

Rousseff, D. Statement by H. E. Dilma Rousseff, president of de Federative Republic of Brazil, at the opening of the General Debate of the $66^{\text {th }}$ Session of the UNited Nations General Assembly. September 21, 2011 . Accessed February 4, 2018. https://gadebate. un.org/sites/default/files/gastatements/66/BR_en_0.pdf

Rousseff, D. Press statement by the President of Brazil after the VI Brazil-EU Summit. January 24, 2013, 15:58, last modified July 04, 2014, 20:14. Accessed February 4, 2018. http://www2.planalto.gov.br/acompanhe-o-planalto/discursos/discursos-da-presidenta/ declaracao-a-imprensa-da-presidenta-da-republica-dilma-rousseff-apos-a-vi-reuniao-decupula-brasil-uniao-europeia

Russia Federation. Constitution of the Russian Federation: Adopted on 12 December 1993. Moscow: Rossiiskaya Gazeta. Accessed February 5, 2018. http://www.constitution.ru/ en/10003000-01.htm

Russian Federation. Concept of the Foreign Policy of the Russian Federation: Approved by President of the Russian Federation V. Putin on 12 February 2013. Moscow: Ministry of Foreign Affairs, 2013. Accessed January 29, 2018. http://www.mid.ru/en/foreign_policy/ official_documents/-/asset_publisher/CptICkB6BZ29/content/id/122186

Sakwa, R., M. Galeotti, and H. Balzer. Putin's third term: Assessments amids crisis. Washington, D.C.: Center on Global Interests, 2015.

Schweller, R. "Emerging Powers in an Age of Disorder." Global Governance 17, no. 3 (2011): 285-97.

Serbin, A, and A. Serbin Pont. "Latin America and the Responsibility to Protect: Divergent Views from the." Pensamiento Propio 41, no. spe. (2015): 11-34.

Smith, K. "South Africa and the Responsibility to Protect: From Champion to Sceptic." International Relations 30, no. 3 (2016): 391-405. doi: https://doi.org/10.1177/0047117816659596.

Snetkov, A., and M. Lanteigne. “The Loud Dissenter and Its Cautious Partner' - Russia, China, Global Governance and Humanitarian Intervention.” International Relations of the Asia-Pacific 15, no. 1 (2015): 113-46. doi: https://doi.org/10.1093/irap/lcu018. 
South American-Arab Countries. 2012. III Summit of South American-Arab Countries - Lima Declaration. October 3, 2012, 09:28. Accessed February 6, 2018. http://www.itamaraty.gov. $\mathrm{br} / \mathrm{en} /$ press-releases/9158-iii-summit-of-south-american-arab-countries-declaration-of-lima Stuenkel, O., and M. Tourinho. "Regulating Intervention: Brazil and the Responsibility to Protect." Conflict, Security \& Development 14, no. 4 (2014): 379-402. doi: https://doi. org/10.1080/14678802.2014.930593.

Tsygankov, A. P. 2016. Russia's Foreign Policy: Change and Continuity in National Identity. London: Rowman \& Littlefield, 2016

Tourinho, M. "For Liberalism without Hegemony: Brazil and the Rule of Non-Intervention". In Brazil on the Global Stage: Power, Ideas, and the Liberal International Order, edited by O. Stuenkel, and M. M. P, Taylor, 79-94. London: Palgrave Macmillan US, 2015. doi: https://doi.org/10.1057/9781137491657.

Trenin, D. "Moscow the Muscular: The Loneliness of an Aspiring Power Center." Briefing 11, no. 1 (2009): 1-12. Accessed January 27, 2018. http://www.css.ethz.ch/en/services/ digital-library/publications/publication.html/137383

United Nations General Assembly. Resolution adopted by the General Assembly Res 60/1 2005 World Summit Outcome. October 24, 2005. Accessed February 1, 2018. http:// www.un.org/womenwatch/ods/A-RES-60-1-E.pdf

United Nations Security Council. Resolution 1973 (2011) Adopted by the Security Council at its 6498th meeting, on 17 March 2011. March 17, 2011. Accessed February 1, 2018. https:// www.nato.int/nato_static/assets/pdf/pdf_2011_03/20110927_110311-UNSCR-1973.pdf

Vaz, A. C. "Rising Powers and International Intervention: The Constraints in Collective Action." In Brazil as a Rising Power: Intervention Norms and the Contestation of Global Order edited by P. Cunliffe, and K. M. Kenkel, 21-41. [n.p.]: Routledge, 2016.

Vieira, A. V. G. "Ukraine, Russia and the Strategic Partnership Dynamics in the EU's Eastern Neighbourhood: Recalibrating the EU's 'Self', 'We' and 'Other'." Cambridge Review of International Affairs 29, no. 1 (2016): 128-50. doi: https://doi.org/10.1080/09557571.2015.1093410.

Vigevani, T., and Cepaluni, G. Brazilian Foreign Policy in Changing Times: the quest for autonomy from Sarney to Lula. [n.p.]: Lexington Books, 2012.

Welsh, J., P. Quinton-Brown, and V. MacDiarmid. 2013. "Brazil 'Responsibility While Protecting' Proposal: A Canadian Perspective. ICRtoP (July 12, 2013). Accessed February 4, 2018. http://www.responsibilitytoprotect.org/index.php/crises/178-otherrtop-concerns/4915-jennifer-welsh-patrick-quinton-brown-and-victor-macdiarmidccr2p-brazils-responsibility-while-protecting-proposal-a-canadian-perspective Wiener, A. A Theory of Contestation. New York, London: Springer, 2014. ZOPACAS. Declaração de Montevidéu. Declaration at Seventh Ministerial Meeting. January 16, 2013. Accessed 6 February, 2018. http://www.defesanet.com.br/geopolitica/ noticia/9324/ZOPACAS----Declaracao-de-Montevideu- 